\title{
The Thermo-Magnetic Properties and History of Some Plutonic Rocks from the Leinster Granite, Ireland
}

\author{
By Horace MANLEY* and David J. BURDON** \\ (Read Oct. 26, 1949)
}

\section{Summary}

The susceptibility and remanent magnetisation have been determined for seven representative samples of the granodiorite, granite and basic enclaves which form the bulk of the Arrigle Complex, lying at the south-west termination of the Leinster Granite. The determinations were made on the rocks in their natural state and again after they had been heated to $600^{\circ} \mathrm{C}$ and cooled in the earth's magnetic field in London. From these have been calculated $X$, the ratio of the susceptibility after and before heating; $S$, the ratio of the thermo-remanent magnetisation to the remanent magnetisation; and $\mathrm{Z}$, the ratio of $Q$ to $T$.

For the granodiorites, $X$ averages about 30 and $\mathrm{S}$ about 50 ; this indicates that new magnetic minerais were developed by heating and suggests that the granodiorites, as now constituted, have not cooled through their Curie point. For the granites, $X$ averages 1.3 and $S$ about 32 ; this indicates that no new magnetic minerals have been developed by heating, but that the remanent magnetisation of existing magnetic minerals has been greatly increased. This proves that the magnetic minerals of the granite have formed below their Curie point; the petrography indicates that magnetite has formed or reformed along with other deuteritic changes, the most important of which is the change of hornblende to a biotite-quartz symplectite. Of the basic enclaves, the gabbroes show $X$ equal to 1.6 and $S$ equal to 2.7 ; this proves that the gabbroes have crystallised and cooled from above their Curie point in the normal manner of igneous rocks. Another enclave, supposedly a porphyretic dolerite, shows $X$ equal to 3.9 and $S$ equal to 21 ; either the dolerite has suffered much low-temperature metamorphism of its magnetic, or potentially magnetic, minerals, or it is a metamorphic rock closely resembling a dolerite.

Thermo-magnetic investigations, combined with petrography, along the lines outlined in this paper should prove of great assistance in the elucidation of the thermal history of many metamorphic-plutonic-igneous rocks.

\section{Contents}

1. Geological setting.

2. Petrology of specimens.

3. Laboratory procedure.

* 124, Brondesbury Villas, Kilburn, London, N.W. 6.

** P.O. Box 256, Damascus, Syria. 
4. Magnetic properties.

5. Thermo-magnetic properties.

6. Discussion:

6.-1. Magnetic properties.

6.-2. Thermo-magnetic properties.

6.-3. Thermal history of the rocks.

7. Acknowledgements and Bibliography.

\section{Geological Setting}

The Caledonian granites of the Leinster chain form a continuous outcrop extending south-south-west for some 70 miles from Dublin to the village of Inistioge in Co. Kilkenny, Fig. 1, A. There is then a gap of some six miles between the end of the main granite outcrop and the present cover of unconformable Upper Old Red Sandstone on the west. Within this gap there are five outcrops of granitic rock. Four of these resemble closely the granite or granodiorite of the main Leinster chain; but the most westernly outcrop, in part covered by the Old Red Sandstone, consists of several different rock-types Fig. 1, B. It has been named 'The Arrigle Complex' from the small river which flows over it; the rocks described in this paper all come from the Arrigle Complex.

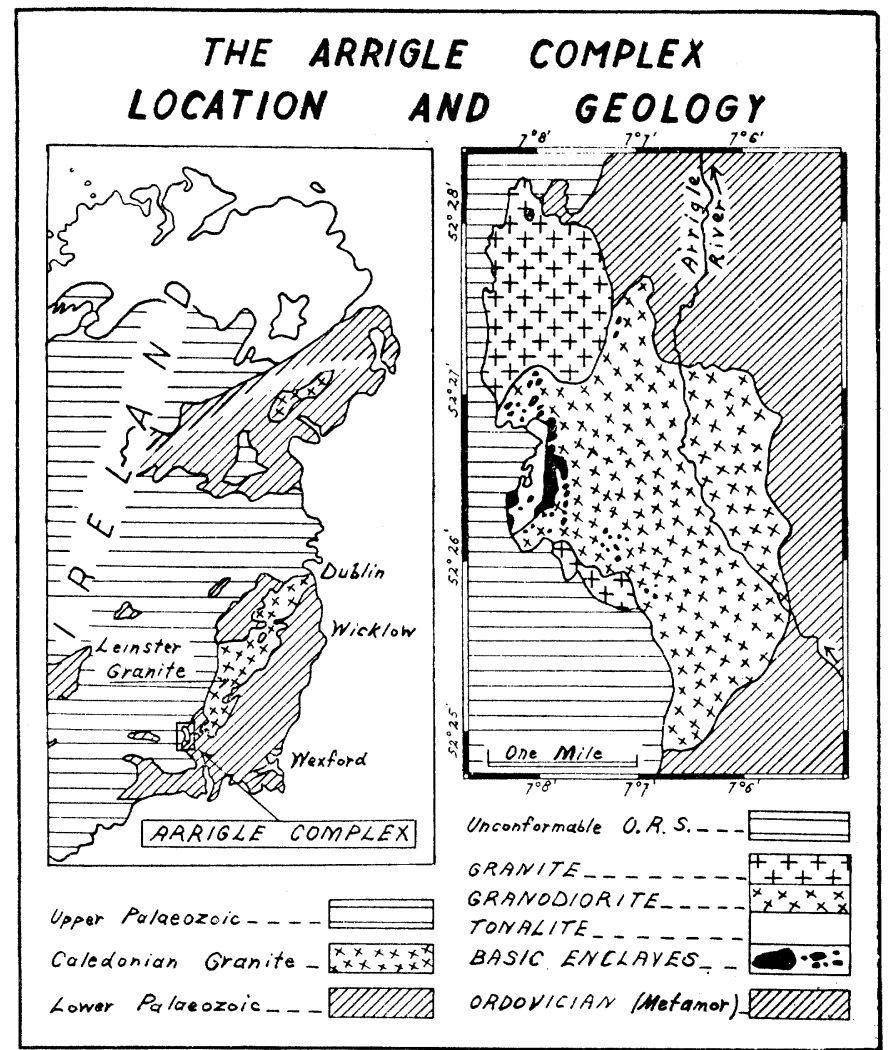

Fig. 1. Generalised geological map of eastern Ireland, showing the relationship of the Arrigle Complex to the Leinster Granite. Details of the geology are shown on the second map. 
The Arrigle Complex consists of five major rock-types :-

(1) Basic Enclaves, gabbroidal to doleritic in texture.

(2) Tonalites, ranging from true Tonalites through Monzotonalits to Adamelites; these are not described in this paper.

(3) Granodiorites, with varying amounts of skialiths of sedimentary origin.

(4) Coarse granophyric Granite.

(5) Fine-grained granophyric Granite, probably a marginal phase of No. 4 ; it is not described in this paper.

In addition, there are the usual dyke associates of a plutonic complex, including granophyric porphyry dykes. A full description of the Arrigle Complex is to be published elsewhere, (by D.J.B.)

Exposures are poor, for there is a cover of light bog and some glacial drift over much of the valley. A magnetic survey was carried out to assist in mapping the basic enclaves, and also to trace their extension beneath the Old Red Sandstone. The interpretation of the magnetic survey necessitated a study of the magnetic properties of the rock-types forming the Arrigle Complex. This was carried out by H.M., who expanded the investigation to cover the thermo-magnetic properties of the rocks. It is considered by the joint authors that from these investigations several important facts concerning the thermo-magnetic, and hence geological, history of the rocks may be deducted.

\section{Petrology of Specimens}

Scven specimens were selected for examination:

4. Basic Enclaves............Specimens Nos. 765, 768, 769, and 770.

1. Granophyric Granite........ Specimen No. 180.

2. Granodiorites ............. Specimens Nos. 134 and 136.

Thin slices for petrographic examination were cut at the time the rock cubes were made. After the heated cubes had had their magnetic properties determined, further slices were cut from the actual cubes. Both sets of slices were examined to see if any petrographic changes could be seen in their constituent minerals, particularily in those with known or suspected thermo-magnetic properties. Due to the rather heterogenous nature of most of the rocks, and consequent changes from slice to slice, the latter investigation has not yielded any striking results.

Basic Enclave No. 7.65. This is a normal medium-coarse gabbro, composed of labradorite, augite and amphibole, with magnetite-ilmenite; the ferro-magnesian minerals are uralitised and chloritised with seperation of rare epidote, while the felspars are locally saussuritised. The labradorite is euhedral, in laths up to $10 \mathrm{~mm}$ long, zoned and twinned. The augite is interstitial to sub-ophitic, and is much changed to green hornblende and chlorite with granular epidote and fibrous actinolite. Some brown hornblende is probably primary. There are some chlorite areas composed of chrysotile laths forming a regular pattern but lacking any lime mineral. The iron ore forms about $3 \%$ of the rock. It is mainly in laths of ilmenite up to $1 \mathrm{~mm}$ long, occuring mainly in the ferro-magnesian minerals. A 
little fine-grained magnetite is seen in some of the uralite areas, while skeleton magnetite occurs in the primary bown hornlende. No leucoxene was seen. Pyrite is present in small amounts, simulating magnetite in its mode of occurrence and possibly forming mixed crystals.

Basic Enclave No. 768. This is a coarse gabbro, with basic labradorite and sub-ophitic augite partially uralitised. There is some primary brown hornblende and some green hornblende which may also be primary. The former presence of bronzite is shown by bastite pseudomorphs; it is even possible that the rock once contained primary olivine. Rods of haematite may be seen in some of the felspar. In general the magnetite occurs in patches, up to $0.5 \mathrm{~mm}$ long, but there is one large area of magnetite in the slide which is $2.5 \mathrm{~mm}$ across. There is also a a sprinkling of fine secondary magnetite formed during the uralitisation and chloritisation of the original ferro-magnesian minerals. Pyrite is common, often in quite large crystals.

This specimen was oriented in the field, and so the cubes cut from it have also been oriented.

Basic Enclave No. 769. This coarse gabbro closely resembles No. 769, but for. the fact that there is a great increase in the number of haematite rods in the labradorite; such heamatite is an exsolution phenomenon and is not unusual in labradorite. The total iron ore content of the rock lies between $4 \%$ and $5 \%$. Around some of the magnetite patches, some deuteritic biotite has developed from the ferro-magnesian minerals: in part, it must replace some of the magnetite. Pyrite is common, but in small grains or agglomerations of grains, not in large crystals as in No. 768 .

This specimen was oriented in the field, and so the cubes cut from it have also been oriented.

Basic Enclave No. 770. This is a porphyretic dolerite, with a scattering of large plagioclase crystal set in a fine-grained base with a somewhat gabbroidal texture. The large felspars are altered to tremolite-actinolite and zoisite; if it were originally labradorite, it contained no haematite rods. The augite of the base has followed the usual augite-to-hornblende and hornblende-to-chlorite changes. The total iron ore present is but $2 \%$, much less than in the other basic enclaves. Skeletal octahedra of magnetite are seen, and there is ilmenite in rods up to $0.7 \mathrm{~mm}$ long. There is a very little pyrite present.

Granophyric Granite, No. 180. This is a representative of the late crosscutting granites which are the most homogeneous rocks of the Arrigle Complex. It is a leuco-granite, with quartz, orthoclase and albite forming $97.3 \%$ of the rock. The albite is subhedral and comparatively fresh. The orthoclase tends to be poekilitic; it is fresh but some areas are clouded with a dusting of fine haematite, apparently introduced from the Old Red Sandstone which till recently covered the outcrop. The quartz is strikingly granophyric; intergrowths are mainly with the orthoclase, but occasionally the albite is involved, suggesting a 
ternary eutectic (see Nockolds, 1947). Green biotite forms $2 \%$ of the rock. It is strongly pleochroic, with $X$ a pale buff and $Y$ and $Z$ a clear dark green; it is almost uniaxial and the birefringnence is low for a mica. It varies in size from well-formed flakes up to $2 \mathrm{~mm}$ long to clots of numerous small flakes; the centre of such clots is usually sieved with quartz granules in a symplectite growth with the biotite. This suggests that it is secondary after a silica-richer ferro-magnesian such as hornblende or amphibole. The lime released in such a change now appears as epidote, grading towards clinozoisite and into allanite. Zoned epidote is seen, and pleochroic haloes occur in the biotite around the epidote/allanite. No zircon was seen. There is a little reddish-brown and grey sphene: in small grains such sphene is almost indistinguishable from allanite. In a few places, alteration of the biotite to chlorite has resulted in the formation of sagenitic rutile. There is a little pyrite present, pseudomorphed by goethite/lepidocrocite. There is a very little magnetite in the biotite, but the total iron ore content of the granite does not exceed $0.5 \%$.

After heating, the granophyric quartz remain unchanged. The pink colour of the orthoclase, and the haematite dust, have been emphasised. But the amount of ore in the felspar has not increased, nor has the haematite changed to magnetite. The albite is clouded; sericite, sometimes stained yellow, has developed and also clinozoisite/zoisite, but no chlorite or epidote are seen in the altered plagioclase. The yellow staining may be goethite or lepidocrocite, and this would involve changes in the iron present. Of all the minerals, the mica shows the most marked changes. It is now red-brown in colour, pleochroic from brownish yellow to dark foxy red. The epidote appears darker in colour. Magnetite may be seen in the mica; it appears to be greater than that noted before heating, but the difference is not greater than might be expected from one slice to another. The haematite in the felspar has not changed to magnetite, and there is no reason why the haematite in the mica should behave differently. No change was observed in the small amounts of allanite and sphene.

Granodiorite No. 134. This specimen represents a comparatively homogeneous portion of the granodiorite, but in it 'skialiths' ('shadowstones,' Goodspeed, 1948, p. 67) may still be recognised; these consist of biotite hornfels and patches of granular quartz. In the body of the rock, the dominant mineral is oligoclase, usually heavily sericitised. The perthitic orthoclase is pockiloblastic and comperatively fresh. Biotite forms about $5 \%$ of the rock and shows a very patchy distribution. Small poekilolithic biotites may be seen in the skialiths while clots of coarser biotite occur throughout the more homogenised body of the rock. Where enclosed on orthoclase, the biotite is fresh; elsewhere it is much altered to chlorite, in which some granular epidote and sphene occur. Zircon and apatite are minor accessories. There is almost no magnetite visible in the slices cut for examination.

Granodiorite No. 136. This is a representative of skialith-rich granodiorite, 
and in the hand-specimen slivers of biotite hornfels and quartz blebs are visible. The slices show the quartz blebs to consist of aggregates of rounded grains cemented by a thin coating of limonite. The hornfels consist of small biotites in a base of quartz and clouded oligoclase. There is some poekiloblastic orthoclase in the body of the rock, which closely resembles that of No. 134. The biotite is much altered to chlorite, in which sagenitic rutile is common; one small crystal of goethite was seen with the rutile. The amount of magnetite is extremely small, but there are a few specks of pyrite, with a goethite/limonite rim. The rock is so heterogeneous that each slice will vary considerably from the average for the rock.

\section{Laboratory Procedure}

In order to make the magnetic observations, the specimens had to be cut into cubes with sides $2 \mathrm{~cm}$ long. This was done by means of a specially designed rock-cutting machine designed by $\mathrm{H}$. M. in co-operation with Dr. Bruckshaw. It consists of a diamond-impregnated copper disk spun at 3,000 rpm by an electric motor. Where oriented cubes were required, the initial cut was made parallel to the paint-marks on the field specimen, the operator holding the rock in his hands. Thereafter the remaining five faces were cut with the aid of a jig, and a true cube obtained from the randomly-shaped specimen; if the latter had been oriented in the field, the resulting cube or cubes were also oriented. In all 25 cubes were cut from the 7 field samples examined.

The method of making the magnetic observations and calculations has been fully described by Bruckshaw and Robertson (1948); the same apparatus and procedure were used in this investigation. The direction and intensity of the remanent magnetisation was determined for each cube in three perpendicular directions. From this the amount and direction (for oriented specimens), of the remanent magnetisation were determined. The susceptibility was also found for each cube by measuring its behavior as 'an alternating magnet under the action of the changing energizing field'.

These observations were made on the cubes before and after they had been heated to above $600^{\circ} \mathrm{C}$ in a furnace. The results are tabulated in Tables 1 and 2 .

No attempt was made to determine the Curie point directly. By heating samples of Nos. 134 and 180 to $300^{\circ}, 500^{\circ}$, and $600^{\circ} \mathrm{C}$ successively, it was determined that the Curie point for these rocks was higher than $500^{\circ} \mathrm{C}$, and probably close to $600^{\circ} \mathrm{C}$; see Chevallier et Piere, 1932. Specimen No. 134 showed an appreciable increase in susceptibility (13) and a large increase in remanent magnetisation (32) after heating to $600^{\circ} \mathrm{C}$; whatever mineral altered to magnetite, or another magnetic mineral (?), did so close to the Curie point of magnetite, which lies around $570^{\circ} \mathrm{C}$ for pure magnetite. Specimen 180 showed almost nil (1.3) increase in susceptibility but a marked increase (45) in remanent magnetisation; whatever mineral already in the rock took-on its latent residual magnetisation on cooling around $600 \mathrm{C}$, did so close to the Curie point of magnetite. Similar results were obtained by Michel- 
Levy et Grenat, (1929), Grenat (1930), Nagata (1943) and others in similar investigations into rocks. It is concluded that the magnetic constituent is magnetite.

Due to the low concentration of the magnetite in the natural rocks and to its low susceptibility, no attempt was made to extract the amount required for an $\mathrm{X}$-ray powder analysis.

\section{Magnetic Properties}

The following magnetic properties were determined for the rocks in their natural state:-The susceptibility $\left(k_{n}\right)$ and the remanent magnetisation $(R)$ for all specimens and also the angle and direction of magnetic dip for the oriented specimens. With its remanent magnetisation, a rock possesses an induced magnetisation due to the earth's magnetic field $(H)$; the value of this induced magnetisation, $k_{n} H$, is readily obtained by multiplying the susceptibility by the intensity of the earth's local magnetic field. In the laboratory, $H$ equals 0.545 oersted. The ratio of $R$ to $k_{n} H$ is called ' $T$ ', and is a measure of the magnitude of the remanent/induced magnetisation.

Table 1 shows the results obtained. At least two cubes had been cut from each rock specimen, and in all 25 cubes were investigated. Where approximately the same figures were obtained on two or more cubes cut from the same rock, the values are not repeated in Table 1 , but suffixes ' $a$,' ' $b$,' etc. have been added to indicate the number of cubes measured.

Table 1. Magnetic properties of natural rocks prior to heating. The general accuracy equals $10 \times 10^{-6}$ c.g.s. units. Susceptibility and Remanent Magnetisation are expressed in $10^{-1 ;}$ c.g.s. units. N.D. means 'not determind'.

\begin{tabular}{|c|c|c|c|c|c|}
\hline $\begin{array}{l}\text { Rock Type and } \\
\text { Specimen No. }\end{array}$ & $\begin{array}{c}\text { Susceptibility } \\
k_{n}\end{array}$ & $\begin{array}{c}\text { Remanent Mag. } \\
R\end{array}$ & Ratio $R / k_{n} H$ & Dip & Declin. \\
\hline Basic Enclaves & & & & & \\
765, a, b & 105 & 120 & 2.0 & - & - \\
768, a & N.D. & 370 & N.D. & $-33^{\circ}$ & E. $148^{\circ}$ \\
768, b & N.D. & 260 & N.D. & $-25^{\circ}$ & E. $162^{\circ}$ \\
768, c & 270 & 270 & 1.8 & - & - \\
769, a & 375 & 810 & 4.0 & $-38^{\circ}$ & E. $115^{\circ}$ \\
769, b & 155 & 525 & 6.2 & $-30^{\circ}$ & E. $115^{\circ}$ \\
770, a, b, c & 90 & 40 & 0.8 & - & - \\
Granites & & & & & - \\
180, a, b, c, d & 125 & $<10$ & $<0.15$ & - & - \\
Granodiorites & & & & & - \\
134, a, b, c, d & 20 & $<10$ & $<0.9$ & - & - \\
136, a, b, c, d, & Nil & Nil & - & - & - \\
\hline
\end{tabular}

\section{Thermo-Magnetic Properties}

When the foregoing measurements had been completed, the cubes were heated to $600^{\circ} \mathrm{C}$ in a furnace and then allowed to cool slowly to room temperature in the earth's magnetic field. In so cooling through its Curie Point (which could not be greater than $580^{\circ} \mathrm{C}$ ), each cube acquired new magnetic properties. 
These new magnetic properties were measured in exactly the same manner as that used on the unheated-treated rocks. Table 2 shows the results obtained. The new susceptibility is indicated by ' $k$ ' and the new remanent magnetisation by ' $P$ '; this may be described as the thermo-remanent magnetisation of the specimen. The ratio of $P$ to $k_{t} H$ is indicated by ' $Q$ '. This ratio is of considerable interest and diagnostic use. It was first introduced by Koenigsberger $(1933,1938)$; Thellier (1938) and Nagata $(1941,1943)$ have shown that it is a magnetic characteristic of rocks, independant of the field strength for small field intensities.

Table 2. Magnetic properties of the rocks after they had been heated to $600^{\circ} \mathrm{C}$, and allowed to cool in the earth's magnetic field. Susceptibility and Remanent Magnetism are expressed in 10-6 c.g.s. units.

\begin{tabular}{|c|c|c|c|c|}
\hline $\begin{array}{c}\text { Rock Type and } \\
\text { Specimen No. }\end{array}$ & $\begin{array}{c}\text { Susceptibility } \\
k_{t}\end{array}$ & $\begin{array}{c}\text { Remanent Mag. } \\
P\end{array}$ & $\begin{array}{r}\text { Ratio } P / k_{t} H \\
Q\end{array}$ \\
\hline Basic Enclaves & & & & \\
765, a & 165 & 320 & 3.5 & $61^{\circ}$ \\
765, b & 165 & 330 & 2.8 & $59^{\circ}$ \\
768, a & 350 & 1,225 & 6.5 & - \\
768, b & 270 & 540 & 4.3 & - \\
768, c & 290 & 1,520 & 9.7 & $64^{\circ}$ \\
769, b & 285 & 1,150 & 7.4 & $64^{\circ}$ \\
770, a & 390 & 1,025 & 4.8 & $68^{\circ}$ \\
770, b & 310 & 680 & 4.0 & $65^{\circ}$ \\
770, c & 345 & 840 & 4.5 & $69^{\circ}$ \\
Granites & & & & \\
180, a & 230 & 420 & 3.4 & $65^{\circ}$ \\
180, b & 135 & 235 & 3.2 & $68^{\circ}$ \\
180, c & 155 & 290 & 3.5 & $67^{\circ}$ \\
Granodiorites. & & & & \\
134, a & 330 & 570 & 3.2 & $68^{\circ}$ \\
134, b & 115 & 200 & 3.2 & $67^{\circ}$ \\
134, c & 335 & 570 & 3.1 & $63^{\circ}$ \\
136, a & 400 & 830 & 3.8 & $67^{\circ}$ \\
136, b & 375 & 735 & 3.6 & $64^{\circ}$ \\
136, c & 275 & 620 & 4.1 & $68^{\circ}$ \\
136, d & 250 & 470 & 3.5 & $67^{\circ}$ \\
136, e & 275 & 600 & 4.0 & $70^{\circ}$ \\
136, f & 330 & 685 & $69^{\circ}$ \\
\hline
\end{tabular}

It will be noticed that the heated cubes take on the magnetic dip approximating to that measured for the laboratory, $\left(65^{\circ}\right)$; the mean value for the cubes is $66^{\circ}$, and the range extends from $59^{\circ}$ to $70^{\circ}$. Sample 769 , a completely disintegrated during heating, and $769, \mathrm{~b}$ was severely fractured. This phenomenon is rare and may be due to the expulsion of volatiles or to the release of strain at moderately high temperature.

The ratios of the the sets of values given in Tables 1 and 2 have been 
calculated and are given in Table 3. The ratio of the susceptibility after heating to the susceptibility bofore heating is called ' $X$ '; any departure of this ratio from unity may be taken as implying a formation or destruction of magnetic constituents in the rock by and during the heat treatment process. The ratio of the thermoremanent magnetism after heating to the remanent magnetism of the natural rock is called ' $S$ '; its interpretation is by no means simple. Finally, the ratio of $Q$ to $T$ is called ' $Z$ '; this $Z$ ratio is the $S$ ratio corrected for changes of susceptibility produced by the heat treatment.

Table 3. Ratios between the Susceptibilities, Remanent-Induced Magnetisation and Remanent Magnetisation after and before heating to $600^{\circ} \mathrm{C}$.

\begin{tabular}{|c|c|c|c|}
\hline $\begin{array}{c}\text { Rock Type and } \\
\text { Specimen No. }\end{array}$ & Ratio $k_{t} / k_{n}$ & Ratio $P / R$ & Ratio $Q / T$ \\
\hline Basic Enclaves & & & $Z$ \\
765, a & 1.6 & 2.7 & 1.7 \\
765, b & 1.6 & 2.8 & 1.8 \\
768, a & N.D. & 3.3 & N.D. \\
768, b & N.D. & 2.1 & N.D. \\
768, c & 1.1 & 3.6 & 5.4 \\
769, b & 1.8 & 2.0 & 1.2 \\
770, a & 4.3 & 26. & 6.0 \\
770, b & 3.5 & 17. & 5.0 \\
770, c & 3.8 & 21. & 5.6 \\
Granites & & & \\
180, a & 1.7 & 40. & 23. \\
180, b & 1.1 & 25. & 16. \\
180, c & 1.2 & 30. & 23. \\
Granodiorites & & & \\
134, a & 16. & 55. & 3.5 \\
134, b & 6. & 20. & 3.5 \\
134, c & 17. & 55. & 3.5 \\
136, a & 40. & large & - \\
136, b & 40. & large & - \\
136, c & 30. & large & - \\
136, d & 25. & large & - \\
136, e & 30. & large & - \\
136, f & 35. & large & - \\
\hline
\end{tabular}

\section{Discussion 6.-1. Magnetic Properties}

The figures for remanent magnetisation given in Table 1 indicate a sharp division of the rocks into two groups; a similar, but less sharp, division may be made on the figures for susceptibility. The basic enclaves show appreciable susceptibility and remanent magnetisation; the granite and granodiorites are markedbly low susceptibility and almost no remanent magnetisation. This general grouping of the rocks investigated corresponds to the known geological facts: basic rocks are normally more magnetic than those at the acid end of the series. 
Considering the basic enclaves as a group, it is seen that the three gabbroes (Nos. 765, 768 and 769) are very similar. Susceptibilities range from 375 to 105, remanent magnetisation from 810 to 120 , and $T$ values run from 6.2 to 1.8. The magnetic properties of the fourth enclave, No. 770, are very different, and the rock is a porphyretic dolerite. Susceptibility is 90 , the remanent magnetisation is but 40 , while $T$ is 0.8 . Other workers in this field have tentatively established the criterion that rocks with $T$ values above 3 , and possibly above 2, have crystallised and cooled through their Curie point, (Nagata, 1943). This criterion would establish the high-temperature origin of the gabbroes and at the same time suggest that the porphyretic dolerite was of low-temperature origin.

The granophyric granite shows appreciable susceptibility, and a very little magnetite was seen in the slices. Hence the extremely low remanent magnetisation indicates that the rock has not cooled from above its Curie point, or that new low-temperature magnetic minerals have been added after cooling, or that the rock has an abnormally low coercivity. The last explaination is rejected, for magnetic rocks in general have a high coercivity. The thermo-magnetic properties will permit the elimination of one of the two remaining explanations.

The granodiorites have low to nil susceptibility and remanent magnetisation. Virtually no magnetite was seen in the slices. The lack of susceptibility also indicates that no magnetic minerals are now present; hence little can be learnt of the thermal or geological history of the rock from an investigation confined to its magnetic properties.

Information regarding the absolute direction and sign of the dip of the basic enclaves is based on two oriented specimens obtained from in situ outcrops; from these oriented cubes were cut. The error lies within $5^{\circ}$. Table 1 shows that the dip is around $30^{\circ}$, and that there was a reversal of magnetism. The declination for one specimen was $155^{\circ}$, and for the other $115^{\circ}$. These results do not necessarily indicate a reversal of the earth's magnetic field towards the close of the Caledonian orogeny. The basic enclaves were presumably free to move and rotate within the fluid granodiorite, whether the latter is considered as a magmatic or metasomatic product. Clearly this line of investigation would enable the amount of relative movement undergone by different enclaves to be determined, but only significantly if a great number of in situ enclaves could thus be investigated.

\section{Discussion 6.-2. Thermo-magnetic Properties}

Basic Enclaves. The 765 samples have increased their susceptibility by $60 \%$ and their remanent magnetisation by a factor of 2.7 , giving a $Z$ ratio of 1.7 . This $Z$ value implies that the rock has lost $40 \%$ of its remanent magnetism if the earth's magnetic field was then of the same strength as it is today, or that the minimum field in which the rock cooled was 0.31 gauss. The $769 \mathrm{~b}$ sample increased susceptibility by $80 \%$ and doubled its remanent magnetisation, giving a $Z$ ratio of 1.2 . This $Z$ value implies that the rock has lost $17 \%$ of its remanent 
magnetisation if the earth's magnetic field was then of the same strength as it is today, or that the minimum field in which the rock cooled was 0.46 gauss. The differences in the estimates of the minimum terrestrial field some 400 million years ago may be due to different coercivities in the two rocks, or to the fact that only minimum values can be estimated.

Only incomplete results are available for sample 768 . The high $Z$ ratio would suggest that the rock has not passed through its Curie point, but this is not supported by other evidence.

The 770 specimens have increased susceptibility by $290 \%$, and their remanent magnetisation by a factor of 21, giving a $Z$ ratio of 5.5. The increase in susceptibility is sufficiently large to indicate that some mineral which can thermally change to magnetite has been deposited in the rock after cooling, or that the rock has never before been heated above its Curie point. The high $Z$ ratio also implies that this rock has never before been above its Curie point, for there are no reasons to believe that it has demagnetised more rapidly than the other rocks of the group.

Granite. The 180 samples have increased their susceptibility by the low factor of $30 \%$, but their remanent magnetisation by the extremely large factor of 32 , giving a $Z$ ratio of 21 . Even allowing for the fact that the initial remanent magnetisation may have been in error by $50 \%$, since it was so low, this change is far greater than that found for other rocks in this present investigation, or in the literature on this subject. Likewise the $Z$ ratio is the highest encountered, but the $Q$ ratio is very close to the average for all the rocks from the Arrigle Complex.

Granodiorites. The 134 samples have increased their susceptibility by a mean factor of 13 and their remanent magnetisation by 36 ; the resultant $Q$ and $Z$ ratios are quite normal at 3.2 and 3.5 respectively. The 136 samples have behaved in a similar manner, though the increased susceptibility shows a factor of 33 and the remanent magnetisation factor is of the order of 50; however the $Q$ ratio is quite normal at 3.8, and the indeterminate $S$ ratio may also be normal. The heat treatment has therefore brought about the formation of new magnetic minerals in the rock, as witnessed by the high $X$ values. As the rock cooled, these new magnetic minerals passed through their Curie point, and the great increase in the thermo-remanent magnetisation is shown by the high $S$ values. The new magnetic mineral is taken as magnetite.

\section{Discussion 6.-3. Thermal and Geological History of the Rocks}

The magnetic changes produced by heating a rock above its Curie point and allowing it to cool in a magnetic field whose strength is close to that of the earth's may be considered under two heads:-

(i) The heating may alter the magnetic properties of the magnetic mineral already present in the rock.

(ii) The heating may cause new magnetic minerals to form from the pre- 
existing minerals presesent in the rock.

The effect of (i) should be to alter the remanent magnetisation yet leave the susceptibility unchanged or very little changed. The effect of (ii) should cause the susceptibility to increase, and since new magnetic minerals will have been formed, the remanent magnetisation will also increase. Of course the two effects may be produced in the same rock undertreatment, while other rocks will contain no magnetic minerals before or after the heat-treatment. Such peculiar effects as the destruction of magnetic minerals by the heat-treatment, or the imparting of 'latent magnetic properties' to pre-existing minerals are not considered. And it is assumed that the rocks will have the normal high coercivity.

Table 4. Utalisation of the natural magnetic and the thermo-magnetic ratios of rocks to assist in the diagnosis of their thermal history.

\begin{tabular}{|c|c|c|}
\hline \multirow{2}{*}{$\begin{array}{c}\text { Remanent } \\
\text { Magnetisation }\end{array}$} & \multicolumn{2}{|c|}{ Susceptibility } \\
\cline { 2 - 3 } $\begin{array}{c}\text { Unchanged } \\
\text { by Heating }\end{array}$ & $\begin{array}{l}\text { Case A. Gives a valid indication } \\
\text { that the rock has previously cooled } \\
\text { through its Curie point. }\end{array}$ & Case B. Impossible. \\
\hline $\begin{array}{c}\text { Increased } \\
\text { by Heating }\end{array}$ & $\begin{array}{l}\text { Case C. Gives a valid indication } \\
\text { that the rock has not previously } \\
\text { cooled through its Curie point. }\end{array}$ & $\begin{array}{l}\text { Case D. This is not disagnostic. } \\
\text { previously cooled the } \\
\text { Curie point. }\end{array}$ \\
\hline
\end{tabular}

It may be accepted that magnetite is the magnetic mineral with which this investigation is dealing. It has been indicated (Herroun and Hallimond, 1943, p. 220) that the only satisfactory explanation for the remanent magnetisation found in many natural rocks is that the magnetite took on its permanent remanent magnetisation in cooling through its Curie point. The Curie point for pure magnetite has been determined as lying between $580^{\circ}$ and $570^{\circ} \mathrm{C}$; impurities lower this temperature, (Chevallier et Piere, 1932). The Curie point for the rocks from the Arrigle Complex has been fixed roughly as around $550^{\circ}$ to $580^{\circ} \mathrm{C}$ (see Section 3 above).

Some temperatures at which silicate minerals crystailise are of interest for comparison. The albite-oligoclase plagioclase felspars commence to crystallise around $1400^{\circ} \mathrm{C}$. The eutectic for quartz-orthoclase is $800^{\circ} \mathrm{C}$ and the hypertectic is $680^{\circ} \mathrm{C}$. Quartz-orthoclase-hornblende has a ternary eutectic point at $680^{\circ} \mathrm{C}$. Primary magnetite in such rocks is usually considered to be one of the first minerals to crystallise; it should do so at temperatures high above its Curie point, and under such circumstances should take-up a strong remanent magnetisation. When it does not do so, the theory that it has cooled from a high-temperature 'magma' falls under suspicion.

The application of these arguements to the basic enclaves show that the three gabbroes (Nos. 765, 768 and 769) are normal igneous rock which cooled from above the Curie point of their magnetic constituents. They fall into Case A of Table 4. This is in harmony with the petrography and presumed geological 
history of these rocks.

The porphyretic dolerite (No. 770) occurs as a basic enclave in the granodiorite, but appears to have a very different thermal history from the gabbroes: it falls into Case D of Table 4. Magnetite is developed on heating to above the Curie point, and all the indications are that the rock as at present constituted has not previously passed through its Curie point. There are two possible geological explanations of the phenomenon in this case. After the dolerite had cooled through its Curie point, low-temperature metamorphic changes may have destroyed all the magnetic minerals; these reformed when the rock was again heated in this investigation; the metamorphic changes may have occurred when the dolerite was engulphed by the granodiorite. It is not easy to see why the same changes did not affect the gabbroes. On the other hand, the dolerite might be a metamorphic rock, derived say from volcanic ash, passing through a hornfels stage into a pseudo-dolerite. The porphyries rather favour this theory, but otherwise the petrography denies it. The investigation has focussed attention on the uncertainty of the origin of what would otherwise be taken for a normal igneous dolerites.

The granophyric granite (No. 180) falls into Case B of Table 4 ; the susceptibility has barely increased while the remanent magnetisation has increased enormously. This indicates that the rock, as at present constituted, has not previously passed through its Curie point. At first sight, this appears as a startling result, for the geological evidence points to the granophyric granite as a late cross-cutting intrusive granite, while the petrography indicated that it has crystallised from a molten silicate smelt. The iron ore introduced from the Old Red Sandstone (or even from some other source) does not affect the question. It is seen to be haematite before heating and to remain haematite after heating. However, the petrographic examination of the slices indicated that there had been late-stage deuteritic alteration of hornblende into biotite with exsolution of silica as quartz blebs. At the same time, the magnetite seen in small quantities in the biotite may have formed; such magnetite would be low-temperature magnetite and would have low or nil remanent magnetisation. On heating in the laboratory, the existing magnetite would pass through its Curie point and then obtain its remanent (or thermo-remanent) magnetisation. This is considered to be the correct explanation. The main body of the rock crystallised at high temperature; the magnetite is deuteritic, but its idioblastic habit makes it liable to be identified as primary idiomorphic magnetite.

Both the granodiorites (Nos. 134 and 136) fall into Case D of Table 4 ; thus they resemble the porphyretic dolerite No. 770). New magnetite appears to have been created; it could form from low-temperature minerals belonging to the skialithic portion of the granodiorite, or from low-temperature or decomposed high-temperature minerals belonging to the body of the granodiorite. From this it is clear that the magnetic, or potentially magnetite forming, minerals of the granodiorite as found in the field, are low-temperature minerals, whether or not 
they originated from high-temperature minerals. The examination did not reveal what minerals were changed into magnetite on heating; Michel-Levy (1929) considered that sphene decomposed on heating, but it could hardly form appreciable amounts of magnetite.

It is concluded that the relation between the magnetic and the thermomagnetic properties of rocks yields much information as to the thermal and geological history of the rocks, but that this information must be used with caution and must be governed by the history of the rock as revealed by its petrography and other geological features.

\section{Acknowledgements and Bibliography}

This investigation formed part of seperate theses submitted for the $\mathrm{Ph} . \mathrm{D}$ degree from the University of London. The author's thanks and acknowledgements are due to Professor H.H. Read and to Dr. J. Mc G. Bruckshaw for advice and encouragement in the carrying out of this work, and to the Anglo-Iranian Oil Company for funds from which the rock-cutting and testing equipment were purchased.

J. Mc G. Bruckshaw, and E.I. Robertson, “The Measurement of Magnetic Properties of Rocks." Jour. Sci. Instr. and Phy. Indust., Vol. 25, pp. 444-446 (1948).

R. Chevallier et J. Piére., “Thermo-Magnetic Properties of Rocks.” Ann. Physique, V, 18, pp. 383-477. (1932).

G.E. Goodspeed, “Origin of Granites,” Mem. No. 28, Geol. Soc. of Amer. pp. 5578. (1948).

G. Grenat, “Sur les propriétés magnétiques des roches.” Ann. Physique, Tome XIII, pp. 263-348. (1930).

E. Herroun, and A.F. Hallimond, "Laboratory Experiments on the Magnetism of Rocks." Proc. Phys. Soc., Vol. LV, pp. 214-221. (1943).

J.G. Koenigsberger, “Residual Magnetism and the Measerement of Geologic Time.” XVI Inter. Geol. Congress, Vol. I, pp. 225-231. (1933).

J.G. Koenigsberger, “Natural Residual Magnetism of Eruptive Rocks.” Terr. Mag. Atmos. Elect., Vol. 43, pp. 119-130 and 299-320. (1938).

H. Manley, “An Estimate of the Time taken for a Dyke to Cool through its Curie Point." Geofis. Pura Appli., Milan. Vol. 27, pp. 105-109. (1954).

A. Michel-Lévy, et G. Grenat, “Relations entre l'augmentation de la susceptibilité magnétique de certaines roches chauffées et les modifications de leur mineraux constituents" Compt. Rendu., Tome 188. (1929).

T. Nagata, Bull. Earth. Res. Inst., XIX, pp. 579-596. (1941).

T. Nagata, “The Natural Remanent Magnetism of Volcanic Rocks and its Relation to Geomgnetic Phenomena." Bull. Earthquake Inst. Tokyo Imper. Univ., XXI, pp. 1-196. (1943).

S.R. Nockolds, “The Granite Cotectic Curve.” Geol. Mag., Vol LXXXIV, pp. 19-28. (1947).

E. Thellier, Thesis, Paris (1938). 